\title{
«¿Dejarás el baile por mí?»: la representación de la bailarina como trabajadora en Mujeres que bailan de Manuel Romero
}

\author{
María Eugenia Cadús \\ Universidad de Buenos Aires - \\ Universidad Nacional de las Artes - CONICET
}

\section{Resumen}

El primer peronismo sostuvo una importante política de intervención estatal en todos los ámbitos de la sociedad, así como una particular política cultural. Observamos las posibles repercusiones en el campo de la danza escénica, de la política de «democratización del bienestar» planteada por este gobierno. En este marco analizamos el filme Mujeres que bailan (1949) dirigido por Manuel Romero, protagonizado por Fanny Navarro y Niní Marshall, y con participación del Ballet Estable del Teatro Colón. Indagamos en cómo el ballet constituye aquí el lugar de un mundo mágico-romántico pero a la vez peligroso. Esta concepción proporciona un espacio perfecto para desarrollar una narración con características melodramáticas que se podría decir que educa mostrando «lo nocivo» del mundo del arte. Examinamos el lugar de la mujer trabajadora bailarina de ballet a través de la representación que se realiza con el lenguaje cinematográfico.
Palabras clave:

ballet, género, peronismo, trabajadoras, Manuel Romero. 


\section{Abstract}

In its first two terms, the administration of Argentine President Juan Domingo Perón set forth a cultural project that mirrored its signature "welfare democratization" state policy, focused on expanding social welfare programs. The Keywords:

ballet, gender, peronism, women workers, Manuel Romero. government promoted access, until then very limited, of the popular sectors to the arts, culture, tourism, education, and leisure. Such an expansion of the working classes' cultural consumption challenged the standard definition of so-called «high» culture opposite "popular/mass» culture. This paper examines the film Mujeres que bailan (1949) directed by Manuel Romero, starring Fanny Navarro and Niní Marshall, with the participation of Colón Theater Ballet. I focus on how ballet is represented in the melodramatic narration as a magic and romantic world that is attractive but dangerous at the same time, and on the fact that it educates the audience showing the "harmful» aspect of the art. Within this framework, I examine the role of ballerinas as women workers through cinematographic language.

\section{Introducción}

Mujeres que bailan se estrenó el I2 de mayo de 1949. Dirigida por Manuel Romero, fue protagonizada por Fanny Navarro y Niní Marshall como Catita, y contó con la participación del Ballet Estable del Teatro Colón.

Este filme forma parte de un grupo de películas en el que la danza escénica clásica y moderna - toma protagonismo. Encontramos este corpus - relativamente numeroso si observamos la historia del cine argentino- en la época del primer peronismo (1946-1955). No creemos que esto sea azaroso sino que lo consideramos como una muestra del clima cultural de la época y de las políticas culturales implementadas por este gobierno. En este conjunto de películas estrenadas en un periodo de nueve años, cinco filmes introducen la danza clásica: Donde mueren las palabras ${ }^{1}$ (1946) de Hugo Fregonese, Mujeres que bailan 